\section{Aflibercept in age-related macular degeneration: evaluating its role as a primary therapeutic option}

M Ashraf ${ }^{1}$ and AAR Souka ${ }^{2}$

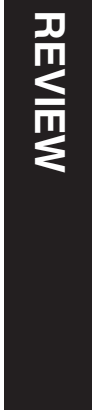

\author{
Abstract \\ The recent VIEW studies have demonstrated \\ the non-inferiority of monthly and bi-monthly \\ aflibercept in the management of wet age \\ related macular degeneration (AMD) com- \\ pared with ranibizumab. However, the current \\ data are limited mainly to fixed dosing regi- \\ mens with few studies looking at flexible \\ dosing regimens of aflibercept in wet AMD. In \\ addition, recent data from the VIEW 96 week \\ extension has shown that patients being \\ shifted from fixed dosing regimens to PRN \\ have shown a drop in visual acuity and \\ increase in central macular thickness. This is \\ an indication that fixed dosing, a non- \\ sustainable option, is only effective as long as \\ it is continued. Regimens such as treat and \\ extend (TAE) and pro-re nata (PRN) have been \\ studied extensively in ranibizumab and bev- \\ acizumab and have shown to be effective \\ options. With the presence of effective, estab- \\ lished and less costly drugs such as ranibizu- \\ mab and bevacizumab, the role of aflibercept \\ as a primary treatment modality has yet to be \\ clearly defined. The current review provides an \\ analysis of the VIEW studies, as well as the \\ extension phases. It also looks at post hoc \\ analysis of predictors of response and out- \\ comes. We have also conducted a search on \\ studies comparing between PRN regimens \\ using aflibercept and other anti-VEGF agents. \\ This review also explores cheaper off label \\ aflibercept; ziv-aflibercept in the treatment of \\ wet AMD. The main purpose of the review is \\ to delineate the role of aflibercept as a primary \\ therapeutic option and if there are any sig- \\ nificant advantages that would advocate its use \\ over alternative anti-VEGF drugs. Finally, we \\ propose a treatment algorithm for patients \\ being started on aflibercept during the first \\ year and thereafter.
}

Eye (2017) 31, 1523-1536; doi:10.1038/eye.2017.81; published online 26 May 2017

\section{Introduction}

AMD is the major cause of visual loss in individuals 50 years or older in developed countries, affecting nearly $10 \%$ of those $>65$ years of age and affects $>25 \%$ of those $>75$ years of age. ${ }^{1}$ Neovascular or wet AMD accounts for $10 \%$ of all patients with AMD and is known to cause severe vision loss. ${ }^{2}$ With the discovery of vascular endothelial factor (VEGF) as a driving factor in CNV development and associated edema, anti-VEGF therapy became the primary treatment modality in the treatment of neovascular AMD. ${ }^{3,4}$ Two landmark RCT (ANCHOR and MARINA) studied the effects of $0.5 \mathrm{mg}$ ranibizumab (Lucentis; Genentech USA Inc, San Francisco, CA, USA) in the treatment of neovascular AMD and demonstrated its efficacy in significantly improving vision in over a third of patients. 5,6

Anti-VEGF agents such as aflibercept (EYLEA; aflibercept solution for injection, Regeneron Pharmaceuticals, Inc, Tarrytown, NY and Bayer HealthCare Pharmaceuticals, Berlin, Germany) have become the mainstay of treatment for wet AMD. ${ }^{7}$ Aflibercept is a fusion protein, combining the key binding domains of VEGF receptors 1 and 2 and the Fc portion of immunoglobulin G. One of the main differences between aflibercept and other anti-VEGF agents (ranibizumab and bevacizumab) is the ability to bind and effectively block VEGF-B and PGF1, in addition to the various VEGF-A isoforms. PGF has been shown in several studies to affect neovascularization in animal models, therefore
${ }^{1}$ Ophthalmology Department, Faculty of Medicine, Alexandria University, In front of 27 Maarouf Rasafi street, Kafr Abdou, Roshdi, Alexandria, Egypt

${ }^{2}$ Ophthalmology Department, Faculty of Medicine, Alexandria University, Egypt

Correspondence: M Ashraf, Ophthalmology Department, Faculty of Medicine, Alexandria University, In front of 27 Maarouf Rasafi street, Kafr Abdou, Roshdi, Alexandria, Egypt

Tel: +201278647125;

Fax: +201278647125 E-mail: Moah384@gmail. com

Received: 27 September 2016

Accepted in revised form: 26 February 2017; Published online: 26 May 2017 
adding to the potential added efficacy of aflibercept compared with ranibizumab. 8,9

The affinity of aflibercept for VEGF-A is substantially greater compared with ranibizumab (94 times) and bevacizumab (120 times). ${ }^{10}$ Because of its greater half-life, mathematical modeling based on animal experimental studies has estimated that the VEGF binding capacity of aflibercept 79 days post injection is equivalent to ranibizumab at 30 days. ${ }^{11,12}$ This led to the suggestion that this could be translated to a longer duration of action of the drug, when injected intravitreally and the possible efficacy of a bimonthly dosing regimen in both Diabetic macular edema and AMD.,13 However, the presence of alternate dosing regimens such as PRN and treat and extend (TAE) for ranibizumab and bevacizumab has led to a debate over the validity of a fixed dosing regimens in favor of more flexible and patient centric regimens. ${ }^{14,15}$

In this review, we will explore the efficacy of aflibercept as a primary treatment modality looking at the various treatment regimens and the comparative data between aflibercept and other anti-VEGF agents. The aim of the present study is to provide a clear understanding of the role of aflibercept in the management of treatment naive patients.

\section{VIEW1/VIEW2: what we learned from the major clinical trials}

The 'VEGF Trap-EYE: Investigation of Efficacy and Safety in Wet AMD' studies (VIEW 1 and 2) were prospective, double-masked, parallel group, active controlled randomized clinical trials. ${ }^{7}$ VIEW 1 was conducted in the United States and Canada, whereas VIEW 2 was conducted in Europe, the Middle East, Asia-Pacific, and Latin America. Patients were randomized in a 1:1:1:1 ratio into four treatment groups; $0.5 \mathrm{mg}$ aflibercept every 4 weeks (0.5q4), $2 \mathrm{mg}$ aflibercept every 8 weeks (2q8); $2 \mathrm{mg}$ aflibercept every 8 weeks after 3 loading doses (2q8) and $0.5 \mathrm{mg}$ ranibizumab every 4 weeks. A total of 1217 patients were randomized in VIEW 1, and 1240 patients were randomized in VIEW 2. Approximately $90 \%$ of patients completed the 52 week follow-up. VIEW 1 and 2 were matched in demographics except that VIEW 2 had a higher percentage of Asians compared with VIEW 1 (20 vs 1\%). In addition, the CNV area was larger in VIEW2 $\left(7.82 \mathrm{~mm}^{2}\right)$ than in VIEW $1\left(6.55 \mathrm{~mm}^{2}\right)$ and post hoc analysis from ANCHOR and MARINA have indicated that large lesion sizes are associated with less visual gains. ${ }^{16,17}$ Furthermore baseline visual acuity was higher in VIEW 1 compared with VIEW 2 (55.125 EDTRS letters vs 52.45).

The primary end point of the study was non-inferiority of intravitreal aflibercept regimens to ranibizumab in the proportion of patients maintaining vision at week 52 (ie, patients losing vision $<15$ letters). Secondary efficacy variables included mean change in BCVA, percentage of patients gaining $>15$ letters, change in total national eye institute 25 item visual function questionnaires (NEI VFQ-25) score; and change in CNV area on fluorescein angiography, as well as retinal thickness and persistent fluid on OCT. The study was not intended to compare between individual aflibercept dosing regimens. Time Domain OCT was used to follow up patients. In VIEW 1 OCT was performed at baseline, week 4, 12, 24, 36, and 52 , whereas in VIEW 2 it was performed at each followup visit. A 96 week extension study was planned where all treatment groups received PRN dosing of the originally assigned drug. All patients were monitored monthly (VA and OCT) and received intra-vitreal injections as needed. Patients not eligible for injections received a mandatory injection at 3 months (12 weeks) regardless their fluid status.

\section{2 week results}

In both VIEW 1 and 2 the proportion of patients who lost $<15$ letters was not statistically different between both treatment drugs indicating the non-inferiority of aflibercept compared with ranibizumab. Approximately $95 \%$ of patients maintained vision, while on anti-VEGF therapy.

The mean change in BCVA was comparable between the different aflibercept groups and ranibizumab in both VIEW 1 and 2 except for the $2 q 4$ group (+10.9 letters) in VIEW 1, which showed a statistically significant superiority to ranibizumab (+8.1 letters). The difference between $2 \mathrm{q} 4$ and ranibizumab was not reproduced in VIEW 2. In addition, the proportion of patients gaining $>15$ EDTRS letters from baseline was similar in all treatment groups. Anatomically, there was a significant reduction in the central retinal thickness in both the ranibizumab and aflibercept treatment arms. However, because the VIEW 2 study measured OCT thickness at monthly intervals, minor fluctuations in the CRT were evident in the 2q8 group between scheduled injections. These fluctuations were more pronounced early during the study amounting to 17 microns and gradually decreased to reach 8 microns by the end of the first year. Furthermore, integrated analysis revealed that the proportion of patients achieving dryness at 52 weeks was $62 \%$ for the ranibizumab group, $72.4 \%$ for the $2 \mathrm{q} 4$ group, $60 \%$ for the $0.5 q 4$ group and $67.7 \%$ for the $2 q 8$ group. A post hoc analysis revealed that the proportion of patients having no fluid on OCT was greater in the aflibercept $2 \mathrm{mg}$ groups compared with the ranibizumab groups.

One drawback of the $2 \mathrm{q} 8$ group was that it mandated that all patients regardless of their fluid status be switched to bimonthly therapy after the first three loading 
doses. A post hoc analysis was conducted to determine whether the fluid status at 12 weeks affected visual outcomes at 52 weeks of therapy. Overall, 35\% of eyes had fluid present compared with $65 \%$ that had achieved dryness. ${ }^{18}$ The percentage of eyes with fluid at 12 weeks were $41.5 \%$ in the ranibizumab group, $30 \%$ in the $2 q 4$ and $33.5 \%$ in the $2 \mathrm{q} 8$ groups. The study also found that compared with ranibizumab treated eyes, eyes treated with aflibercept had a 19-28\% lower chance of having fluid at 12 weeks. In addition, fluid activity at 12 weeks did not seem to affect final visual outcomes. Eyes without fluid at week 12 achieved gains of 9.8, 9.2, and 10.3 letters in the $\mathrm{Rq} 4,2 \mathrm{q} 4$, and $2 \mathrm{q} 8$ groups respectively compared with eyes that had fluid at 12 weeks that achieved gains of $8.8,10.4$, and 8.4 letters for the same treatment groups. The visual outcomes between eyes with fluid and those without fluid at 12 weeks were similar regardless of the treatment drug or regimen $(P=0.1013)$. Anatomically however eyes with no fluid at week 12 were more likely to have a dry macula at 52 weeks regardless of the treatment drug. In addition, eyes with fluid at 12 weeks treated with aflibercept were 1.34 times more likely to achieve a dry macula at 52 weeks compared with eyes treated with ranibizumab (41.4\% for ranibizumab compared with $55.4 \%$ in the $2 \mathrm{q} 4$ and $2 \mathrm{q} 8$ groups).

The time to 'absence of fluid' or 'dryness' was compared between the different drugs and was found that 94 and $92 \%$ in the $2 q 4$ and $2 q 8$ groups respectively had no fluid at least on 1 visit compared with $87 \%$ in the ranibizumab group. ${ }^{19}$ This would seem to indicate that eyes treated with monthly aflibercept were more likely to achieve dryness and were 1.5 times more likely to achieve at least one episode of dryness compared with ranibizumab. The difference between aflibercept and ranibizumab was detected, as early as week 4 indicating the difference in single dose efficacy. Approximately $50 \%$ of eyes treated with aflibercept achieved dryness after the first injection at week, while $75 \%$ of eyes at week 12 had achieved dryness on at least 1 visit. Ranibizumab treated eyes had achieved $75 \%$ dryness on at least 1 visit at week 20 . This demonstrates that aflibercept treated eyes were more likely to achieve dryness and were more likely to achieve it sooner. Sustained dryness, defined by two consecutive episodes of no fluid activity, was higher in the monthly aflibercept group (85\%) compared with $74 \%$ in the bimonthly aflibercept and monthly ranibizumab groups.

\section{6 week results}

In the 96 week extension study patients received their previously assigned anti-VEGF in an as needed regimen (PRN) with mandatory dosing at least every 12 weeks. ${ }^{20}$ A total of 2235 patients entered the second year (91\% of 2457 ) of the study with $\sim 84 \%$ of patients completing the
96 week follow-up. Again, at 96 weeks both aflibercept groups were non inferior to the ranibizumab treatment group with regards to the percentage of patients maintaining vision (average of 95\%). At week 96 the mean VA gains from baseline were 7.9, 7.6, 6.6, and 7.6 letters in the Rq4, 2q4, 0.5q4, and 2q8 groups respectively. This represented a drop of $\sim 1-2$ letters in each treatment group. There was also a minor loss in the anatomic improvements seen at week 52 with patients gaining on average 10 microns in CRT at week 96. In addition, there was also a minor drop in the percentage of patients with no fluid on OCT in all treatment groups. Again it was observed that higher percentages of patients treated with aflibercept had no fluid on OCT compared with patients treated with ranibizumab (mean of $2 q 4-\mathrm{Rq} 4$ was 9\%).

The mean number of injections during the 96 week extension were $4.6,4.1,4.6$, and 4.2 in the ranibizumab, $2 q 4,0.5 q 4$, and $2 q 8$ groups respectively. The number of injections was lower in the aflibercept groups compared with ranibizumab. In addition, higher percentages of patients treated with aflibercept received less than 6 injections compared with the ranibizumab group (15 vs $26.5 \%$ ). This would seem to indicate that for the more resistant cases aflibercept is more effective, requiring less injections.

The anatomical and visual worsening was further explored in a separate post hoc analysis. ${ }^{21}$ The post hoc analyses looked at several subgroups; patients losing $>5$ letters from weeks 52 to 96 , patients losing $>5$ letters from previous BCVA score at week 96 and patients losing $>5$ letters or more at two consecutive visits after the switch in therapy (between weeks 52 and 64). Approximately $20 \%$ of patients regardless of the treatment group lost 5 letters or more after being shifted to PRN therapy. This subgroup had initially achieved significant gains (+8.5 to 10.3 letters) at week 52 , only to loose on average 11 letters by week 96 despite receiving on average 4.5 injections. Visual acuity in this group was finally less than at baseline indicating significant visual loss. Approximately, 23\% of patients showed a loss of 5 EDTRS letters or more between two consecutive monthly visits from weeks 52 to 64 . After receiving anti-VEGF therapy there were some visual improvements although pre-switch visual levels we not achieved. Finally there was a group of patients who received a minimum of 3 injections (12 weekly mandated doses); $43 \%$ in the ranibizumab arm, $54 \%$ in the $2 \mathrm{q} 4,44 \%$ in the $0.5 \mathrm{q} 4$ and $48 \%$ in the 2 q8 group. This group achieved significant visual gains by week 52, and maintained these improvements throughout the extension study. There was no tendency for visual loss or anatomic worsening in this group.

The reason for the drop in vision in a certain subgroup of the population (20-25\%) was demonstrated by 
Schmidt-Erfuth et $a l^{22}$ in another post hoc analysis of the VIEW2 cohort. The study looked at various OCT parameters at monthly intervals including intraretinal cysts (IRC), subretinal fluid (SRF) and pigment epithelial detachment (PED), presenting with a width $>400$ or a height $>200$ microns. The study concluded that IRC at baseline that failed to resolve by week 12 had a negative impact on BCVA consistently showing less visual gains regardless of the treatment regimen (monthly, bimonthly, or during the PRN extension). Although $75 \%$ of eyes had resolution of IRC and SRF, PED was more resistant and showed only a $38 \%$ resolution at 52 weeks. The study also demonstrated that patients that were switched to PRN and lost vision ( $20 \%$ ) usually presented with PED at baseline and had a tendency for PED re-activation and intra-retinal cyst formation. The authors also attributed the inferiority of PRN regimens in previous RCT to this specific cohort. They furthermore advocated continuous fixed dosing for these patients or tight monitoring during PRN therapy. A summary of the major differences between monthly/bimonthly aflibercept and ranibizumab is shown in Table 1.

\section{Fate of eyes with fluid at 12 weeks}

Overall $22.8 \%$ of eyes (413) had persistent fluid activity from baseline to week 12 despite therapy (early persistent fluid). It was lowest in the aflibercept groups (19\%) compared with $30 \%$ in the ranibizumab group (a $34 \%$ lower chance of having fluid for aflibercept treated eyes). The mean change in VA from week 16 to week 52 in patients with residual fluid demonstrated that gains were higher for patients treated with monthly aflibercept $(+11.7$ letters from baseline) compared with monthly ranibizumab (+8.5 letters from baseline) and to bimonthly aflibercept (+7.5 letters from baseline). Pairwise treatment group comparisons showed that the monthly aflibercept group achieved significantly higher gains compared with monthly ranibizumab $(P=0.049)$ and bimonthly aflibercept $(P=0.006)$. However, there was no significant differences between monthly aflibercept and bimonthly aflibercept $(P=0.294)$.

There was no difference between the groups with regards to the number of patients gaining $>15$ letters. However, there was a lower percentage of eyes that lost $>15$ letters in the $2 q 4$ group $(6.5 \%)$ compared with the $2 q 8$ and ranibizumab groups (16\%). A subgroup analysis was performed for different fluid subtypes; intraretinal cysts (IRC) and subretinal fluid (SRF). Patients with early persistent intraretinal cysts at 12 weeks gained on average 6.4-7.3 letters in the 2q8 and ranibizumab groups compared with 11.8 letters in the $2 \mathrm{q} 4$ group. Again with regards to eyes gaining $>15$ letters, patients with early persistent IRC had similar percentages of eyes irrespective of the treatment arm (29.4-31\%). There was a difference however in patients that lost $>5$ letters, with $4.8 \%$ losing vision in the monthly aflibercept group, compared with $16 \%$ in the monthly ranibizumab group and $22 \%$ in the bimonthly aflibercept group. Similar results were seen in eyes with early persistent subretinal fluid (SRF) where eyes that received monthly aflibercept had a higher percentage eyes gaining $>15$ letters and fewer eyes losing $>5$ letters compared with the 2 q8 and monthly ranibizumab groups.

This is an indication that eyes with early persistent fluid at 12 weeks should preferably be treated with monthly aflibercept regardless of the type of intraretinal fluid because of the greater visual gains and less visual loss in these patients compared with patients being treated with monthly ranibizumab and bimonthly aflibercept. In patients with absent fluid at week 12, perhaps flexible dosing regimens such as TAE and PRN could be advocated but they have not been compared directly in a RCT to monthly aflibercept.

\section{Beyond the first year}

Data from the VIEW1/VIEW2 96 week extension have demonstrated that switching from a fixed dosing regimen to a flexible dosing regimen was associated with a 1-2 letter drop. ${ }^{20}$ However, not all groups were similar with approximately half of the patients requiring only the minimum mandatory three injections which is akin to a single injection every 12 weeks. ${ }^{21}$ In addition, there was another subgroup of patients that demonstrated a significant decrease in VA (11 or more letters) and saw them return to baseline visual acuity levels. What is more dramatic was that the drop in VA could be demonstrated as early as the first visit post-switching to flexible dosing. This offers a dilemma to patients being treated with monthly or bimonthly aflibercept with the possibility of patients losing vision if switched to PRN and the non sustainability of a fixed dosing regimen.

An expert panel recently published recommendations as to the best post year 1 strategy for patients being treated with bimonthly aflibercept. ${ }^{23}$ The group highlighted three different strategies post year 1; continued fixed 8 weekly dosing, individualized treat and extend and finally a trial of monitoring without treatment and with extended follow up intervals. The panel recommended fixed bimonthly dosing for patients with active disease but stable visual acuity at the end of year 1 . The panel recommended treat and extend for eyes with inactive disease and stable visual acuity. A final strategy would be to monitor eyes without treatment and would be strictly reserved for eyes that have demonstrated during year 1 or year 2, no signs of activity and stable visual acuity for three consecutive visits. This was based 
Table 1 Comparison between monthly aflibercept, bimonthly aflibercept, and monthly ranibizumab in the VIEW studies.

\begin{tabular}{|c|c|c|c|}
\hline & $\begin{array}{l}\text { Monthly ranibizumab } \\
\quad(\mathrm{Rq4})(\mathrm{n}=306)\end{array}$ & $\begin{array}{l}\text { Monthly aflibercept } \\
\qquad(2 q 4)(\mathrm{n}=304)\end{array}$ & $\begin{array}{l}\text { Bi-monthly aflibercept } \\
\quad(2 q 8)(\mathrm{n}=303)\end{array}$ \\
\hline Change in BCVA from Baseline - week 52 (EDTRS letters) & +8.7 & +9.3 letters & +8.4 \\
\hline Change in BCVA from week 52 - week 96 (EDTRS letters) & -0.8 & -1.7 letters & -0.8 letters \\
\hline \multirow[t]{2}{*}{ Percentage of patients gaining $>15$ letters } & 52 weeks; $32.4 \%$ & 52 weeks; $33.4 \%$ & 52 weeks; $30.9 \%$ \\
\hline & 96 weeks; $31.6 \%$ & 96 weeks; $31.2 \%$ & 96 weeks; $33.4 \%$ \\
\hline \multirow[t]{2}{*}{ Percentage of patients maintain vision } & 52 weeks; $94.4 \%$ & 52 weeks; $95.3 \%$ & 52 weeks; $95.3 \%$ \\
\hline & 96 weeks; $91.6 \%$ & 96 weeks; $92.2 \%$ & 96 weeks; $92.4 \%$ \\
\hline \multirow{2}{*}{$\begin{array}{l}\text { Change in central macular thickness; baseline - week } 52 \\
\text { (microns) }\end{array}$} & VIEW 1; -117 & VIEW $1 ;-117$ & VIEW 1; -129 \\
\hline & VIEW 2; -139 & VIEW 2; -157 & VIEW 2;-149 \\
\hline $\begin{array}{l}\text { Change in central macular thickness; week } 52 \text { - week } 96 \\
\text { (microns) }\end{array}$ & -10 microns & - 10 microns & -6 microns \\
\hline Percentage dry macula week 12 & $58.5 \%$ & $70.2 \%$ & $66.5 \%$ \\
\hline $\begin{array}{l}\text { Percentage of eyes with early persistent retinal fluid on first } 4 \\
\text { visits }\end{array}$ & $30 \%$ & $18.8 \%$ & $20.3 \%$ \\
\hline Percentage dry macula week 52 & $62 \%$ & $72.4 \%$ & $67.7 \%$ \\
\hline Percentage dry macula week 96 & $45.5 \%$ & $54.4 \%$ & $50.1 \%$ \\
\hline Percentage needing $<6$ injections between week 52- week 96 & $73.5 \%$ & $86 \%$ & $84.1 \%$ \\
\hline Percentage needing $>6$ injections between week 52- week 96 & $26.5 \%$ & $14 \%$ & $15.9 \%$ \\
\hline $\begin{array}{l}\text { Retinal fluid status at week } 52 \text { for patients with fluid present } \\
\text { at week } 12\end{array}$ & $41.4 \%$ dry & $55.4 \%$ dry & $55.3 \%$ dry \\
\hline $\begin{array}{l}\text { Retinal fluid status at week } 52 \text { for patients with absent fluid at } \\
\text { week } 12\end{array}$ & $80.4 \%$ dry & $84.8 \%$ dry & $79 \%$ dry \\
\hline Eyes with retinal fluid absent on at least 1 visit at week 52 & $86.9 \%$ & $93.9 \%$ & $91.9 \%$ \\
\hline Proportion of eyes with sustained dryness & $73.7 \%$ & $84.8 \%$ & $73.8 \%$ \\
\hline $\begin{array}{l}\text { Visual acuity gains at week } 52 \text { for eyes with early persistent } \\
\text { retinal fluid }\end{array}$ & +8.5 letters & +11.7 letters & +7.5 letters \\
\hline \multicolumn{4}{|l|}{$\begin{array}{l}P=0.006 \text { for } 2 q 4 \text { vs } 2 q 8, P=0.049 \text { for } 2 q 4 \text { vs } \mathrm{Rq} 4 \text { and } P=0.294 \\
\text { for } \mathrm{Rq} 4 \text { vs } 2 \mathrm{q} 8\end{array}$} \\
\hline $\begin{array}{l}\text { Percentage of eyes with early persistent retinal fluid } \\
\text { gaining }>15 \text { letters }\end{array}$ & $33.7 \%$ & $35.2 \%$ & $31.5 \%$ \\
\hline Percentage of eyes losing $>5$ letters & $6.5 \%$ & $16.6 \%$ & $16.2 \%$ \\
\hline
\end{tabular}

The VIEW studies are Waldstein et al,,$^{34} \mathrm{Jaffe}$ et $a l,{ }^{19}$ Heier et al, ${ }^{7}$ Schmidt-Erfurth et al, ${ }^{20}$ Moshfeghi DM et al..$^{18}$

on the observation that approximately half of eyes in the VIEW extensions received the minimum three injections.

\section{Other studies looking at primary aflibercept}

\section{Implementing the VIEW1/VIEW2 protocol in the real world (bimonthly regimens)}

A retrospective study conducted in the UK looked at EMR records of patients being treated using a bimonthly dosing regimen of aflibercept from 16 National Health Service hospitals (Table 2). ${ }^{24}$ Approximately 1840 treatment naive eyes of 1682 patients were treated with three loading doses followed by bi-monthly aflibercept and were followed up for at least a year.

Mean baseline for the patients was 53.7 EDTRS letters and improved to 58.8 letters, indicating a gain of +5.1 letters. Data were missing for $\sim 28 \%$ of eyes at 1 year. The study found that the largest visual gains were in eyes that started off with worse visual acuity. Eyes with a baseline VA $<35$ letters gained 11 letters, whereas those with a baseline VA 70 letters or more showed a drop of 2 letters.
In addition, $32 \%$ of patients gained 10 letters and $18 \%$ gained 15 letters compared with $8 \%$ who lost $>15$ letters at 1 year of follow-up. The mean number injections was 7 at the end of 52 weeks. The authors concluded that the results of this real world study were comparable to the RCT VIEW1/VIEW2 and that the bimonthly dosing regimen could be a potential option to reduce treatment burdens and follows up for AMD patients.

Four other studies looked at bimonthly dosing in a total of 140 patients and evaluated the efficacy of bimonthly dosing for a period of $\sim 1$ year. ${ }^{25-28}$ The studies showed that patients on average gained +9 EDTRS letters in all studies combined which was equivalent to the results of the larger RCT. Futhermore, the studies looked at a range of different CNV pathologies including PCV, PED and RAP and showed the efficacy of the drug in all subtypes.

\section{PRN regimens with aflibercept}

Two studies looked at the efficacy of aflibercept in a PRN dosing regimen. The study by Kim et al looked at 21 eyes 
Table 2 A summary of previous studies looking at aflibercept as a primary treatment modality

\begin{tabular}{|c|c|c|c|c|c|c|c|}
\hline Author & Study design & Study description & Patients & Follow up & Visual outcomes & $\begin{array}{l}\text { Anatomic } \\
\text { outcomes }\end{array}$ & Other \\
\hline $\begin{array}{l}\text { VIEW1/ } \\
\text { VIEW2 }^{7}\end{array}$ & $\begin{array}{l}\text { Prospective, } \\
\text { double } \\
\text { masked, } \\
\text { randomized } \\
\text { trial }\end{array}$ & $\begin{array}{l}4 \text { groups; } 0.5 \mathrm{mg} \\
\text { ranibizumab } \\
\text { monthly(Rq4), } \\
2 \mathrm{mg} \text { aflibercept } \\
\text { monthly (2q4), } \\
2 \mathrm{mg} \text { aflibercept } \\
\text { bimonthly (2q8) } \\
\text { and } 0.5 \mathrm{mg} \\
\text { aflibercept } \\
\text { monthly (0.5q4) }\end{array}$ & $\begin{array}{l}2419 \text { patients } \\
\text { randomized } \\
\text { in a 1:1:1:1 } \\
\text { ratio }\end{array}$ & $\begin{array}{l}\text { Primary end } \\
\text { point at } \\
12 \text { months. } \\
\text { Extension } \\
\text { period to } \\
96 \text { weeks; PRN } \\
\text { for all groups. }\end{array}$ & $\begin{array}{l}+9.3 \text { letters gain } \\
2 \mathrm{q} 4,+8.7 \text { letter } \\
\text { Rq4 } 4,+8.4 \text { letters } \\
2 \mathrm{q} 8,+8.3 \text { letters } \\
0.5 \mathrm{q} 4\end{array}$ & $\begin{array}{l}\text { Decrease in } \\
\text { CMT (VIEW1/ } \\
\text { VIEW2): } \\
-116 /-130 \\
\text { microns In } \\
0.5 q 4,-117 /-139 \\
\text { microns Rq4, } \\
-117 /-149 \\
\text { microns } 2 \mathrm{q} 8 \text { and } \\
-129 /-157 \\
\text { microns in } 2 q 4 .\end{array}$ & $\begin{array}{l}\text { All groups of } \\
\text { aflibercept were } \\
\text { non inferior to } \\
\text { the ranibizumab } \\
\text { group. }\end{array}$ \\
\hline Talks et al $2^{24}$ & $\begin{array}{l}\text { Retrospective } \\
\text { analysis of } \\
\text { data from } \\
\text { electronic } \\
\text { medical } \\
\text { records }\end{array}$ & $\begin{array}{l}\text { Patients were } \\
\text { treated using a } \\
\text { bi-monthly } \\
\text { treatment } \\
\text { regimen }\end{array}$ & $\begin{array}{l}1840 \\
\text { treatment } \\
\text { naive eyes of } \\
1682 \text { patients }\end{array}$ & 1 year & $\begin{array}{l}\text { Gain of +5.1 } \\
\text { letters }\end{array}$ & $\mathrm{N} / \mathrm{S}$ & $\begin{array}{l}\text { Proportion } \\
\text { achieving } 70 \\
\text { letters or more } \\
\text { increased to } \\
33.7 \% \text {. }\end{array}$ \\
\hline Dirani et al ${ }^{35}$ & $\begin{array}{l}\text { Retrospective } \\
\text { case series }\end{array}$ & $\begin{array}{l}\text { Patients were } \\
\text { treated with } 3 \\
\text { loading doses of } \\
\text { either } \\
\text { ranibizumab } \\
(n=68) \text { or } \\
\text { aflibercept } \\
(n=47)\end{array}$ & $\begin{array}{l}115 \text { eyes of } \\
102 \text { patients } \\
\text { with } \\
\text { treatment } \\
\text { naive AMD } \\
\text { and PED } \\
>150 \\
\text { microns }\end{array}$ & 3 months & $\begin{array}{l}\text { Overall increase } \\
\text { in BCVA by }+7 \\
\text { EDTRS letters. } \\
\text { Drug type did } \\
\text { not affect visual } \\
\text { outcomes. }\end{array}$ & $\begin{array}{l}\text { Decrease in PED } \\
\text { height ( } 368 \\
\text { microns to } 248 \\
\text { microns) and } \\
\text { central retinal } \\
\text { thickness ( } 328 \\
\text { microns to } 198 \\
\text { microns) }\end{array}$ & $\begin{array}{l}\text { Better visual } \\
\text { outcomes was } \\
\text { associated with } \\
\text { lower baseline } \\
\text { BCVA } \\
(P=0.001) \text {, } \\
\text { presence of SRF } \\
(P=0.001) \text { and } \\
\text { RAP }(P=0.001) \text {. } \\
\text { Reduction in } \\
\text { PED height was } \\
\text { associated with } \\
\text { higher PED at } \\
\text { baseline } \\
(P=0.001) \text {, } \\
\text { Serous PED } \\
(P=0.003) \text { and } \\
\text { Aflibercept use } \\
(P=0.022) .\end{array}$ \\
\hline $\begin{array}{l}\text { Zinkernagel } \\
\text { et } a l^{26}\end{array}$ & $\begin{array}{l}\text { Retrospective } \\
\text { interventional } \\
\text { study }\end{array}$ & $\begin{array}{l}\text { Patients } \\
\text { receiving } \\
3 \text { monthly } \\
\text { loading doses } \\
\text { follow by } \\
\text { bimonthly } \\
\text { therapy for } 1 \\
\text { year }\end{array}$ & $\begin{array}{l}26 \text { eyes of } 26 \\
\text { treatment } \\
\text { naive } \\
\text { patients }\end{array}$ & 1 year & $\begin{array}{l}\text { Mean gain in } \\
\text { BCVA was } 9.3 \\
\text { letters }\end{array}$ & $\begin{array}{l}\text { Mean reduction } \\
\text { of CRT was } 154 \\
\text { microns }\end{array}$ & $\begin{array}{l}\text { After } 3 \text { months } \\
\text { resolution of SRF } \\
\text { and IRC in } 80 \% \\
\text { of cases with } \\
\text { increases at } \\
\text { months } 4,6 \text { and } \\
8 \text { (inter-injection } \\
\text { intervals) } \\
\text { Serous PED } \\
\text { displayed See } \\
\text { saw pattern } \\
\text { Fibrovascular } \\
\text { PED remained } \\
\text { stable. }\end{array}$ \\
\hline Kim et $a l^{29}$ & $\begin{array}{l}\text { Retrospective } \\
\text { study }\end{array}$ & $\begin{array}{l}\text { Patients with } \\
\text { treatment naive } \\
\text { wet AMD were } \\
\text { treated with } 3 \\
\text { loading doses of } \\
\text { ranibizumab or } \\
\text { aflibercept and } \\
\text { then treated PRN }\end{array}$ & $\begin{array}{l}30 \text { eyes were } \\
\text { treated with } \\
\text { ranibizumab } \\
21 \text { eyes were } \\
\text { treated with } \\
\text { aflibercept }\end{array}$ & 12 months & $\begin{array}{l}\text { BCVA improved } \\
\text { from } 0.86 \pm 0.45 \\
\text { logMAR to } \\
0.72 \pm 0.56 \\
\text { logMAR in } \\
\text { ranibizumab } \\
\text { group } \\
\text { Mean BCVA } \\
\text { improved form } \\
0.73 \pm 0.37\end{array}$ & NS & $\begin{array}{l}\text { Mean number of } \\
\text { injectinos was } \\
4.5 \pm 1.3 \text { in the } \\
\text { ranibizumab } \\
\text { group and } \\
4.3 \pm 0.9 \text { in the } \\
\text { aflibercept group } \\
\text { No significant } \\
\text { difference } \\
\text { between them in }\end{array}$ \\
\hline
\end{tabular}


Table 2. (Continued)

\begin{tabular}{|c|c|c|c|c|c|c|c|}
\hline Author & Study design & Study description & Patients & Follow up & Visual outcomes & $\begin{array}{l}\text { Anatomic } \\
\text { outcomes }\end{array}$ & Other \\
\hline & & & & & $\begin{array}{l}\log M A R \text { to } \\
0.58 \pm 0.41 \\
\text { logMAR in the } \\
\text { aflibercept } \\
\text { group } \\
\text { No significant } \\
\text { difference with } \\
\text { regards to visual } \\
\text { improvement } \\
(P=0.560)\end{array}$ & & $\begin{array}{l}\text { number of } \\
\text { injections. }\end{array}$ \\
\hline Inoue et $a l^{30}$ & $\begin{array}{l}\text { Retrospective } \\
\text { interventional } \\
\text { comparative } \\
\text { study }\end{array}$ & $\begin{array}{l}3 \text { loading doses } \\
\text { of the drug } \\
\text { followed by PRN } \\
\text { therapy. }\end{array}$ & $\begin{array}{l}200 \text { eyes of } \\
197 \text { patients; } \\
99 \text { patients in } \\
\text { the } \\
\text { ranibizumab } \\
\text { group and } \\
101 \text { patients } \\
\text { in the } \\
\text { aflibercept } \\
\text { group }\end{array}$ & 12 months & $\begin{array}{l}\text { The mean } \\
\text { logMAR visual } \\
\text { acuity at } \\
\text { the baseline was } \\
0.44 \pm 0.33 \text { in the } \\
\text { IVR group and } \\
0.37 \pm 0.37 \text { in the } \\
\text { IVA group. } \\
\text { The mean } \\
\text { logMAR BCVA } \\
\text { at } 12 \text { months } \\
\text { was } \\
0.37 \pm 0.41 \text { in the } \\
\text { IVR group and } \\
0.25 \pm 0.40 \text { in the } \\
\text { IVA group, } \\
\text { respectively, a } \\
\text { significant } \\
\text { improvement } \\
\text { from baseline } \\
P<0.05 . \text { No } \\
\text { significant } \\
\text { difference } \\
\text { between both } \\
\text { treatment } \\
\text { groups. }\end{array}$ & $\begin{array}{l}\text { Mean changes } \\
\text { in CFT at } \\
12 \text { months was } \\
103 \pm \\
130 \mu \mathrm{m} \text { in the } \\
\text { IVR group and } \\
95 \pm 113 \mu \mathrm{m} \text { in } \\
\text { the IVA group, } \\
\text { respectively. } \\
\text { No significant } \\
\text { differences } \\
\text { between the two } \\
\text { drugs. }\end{array}$ & $\begin{array}{l}\text { Median time to } \\
\text { retreatment after } \\
\text { loading doses } \\
\text { was } 5 \text { months in } \\
\text { both groups. } \\
67.7 \% \text { of patients } \\
\text { in the } \\
\text { ranibizumab } \\
\text { group and } 63.4 \% \\
\text { in the aflibercept } \\
\text { group required } \\
\text { retreatment } \\
(P=0.554) .\end{array}$ \\
\hline Oishi et $a l^{27}$ & $\begin{array}{l}\text { Prospective } \\
\text { non } \\
\text { randomized } \\
\text { interventional } \\
\text { case series }\end{array}$ & $\begin{array}{l}3 \text { monthly } \\
\text { loading doses of } \\
\text { aflibercept then } \\
\text { bimonthly } \\
\text { injections for } 1 \\
\text { year }\end{array}$ & $\begin{array}{l}98 \text { patients; } \\
42 \text { had PCV, } \\
46 \text { had } \\
\text { typical AMD } \\
\text { and } 10 \text { had } \\
\text { RAP. }\end{array}$ & 12 months & $\begin{array}{l}\text { Mean logMAR } \\
\text { improved form } \\
0.35 \text { to } 0.21 \text {. No } \\
\text { difference in } \\
\text { improvement } \\
\text { between CNV } \\
\text { subtypes. }\end{array}$ & NS & $\begin{array}{l}\text { Regression of } \\
\text { polyps in cases } \\
\text { of PCV seen in } \\
27 / 42 \text { cases. } \\
\text { Presence of ELM, } \\
\text { smaller greatest } \\
\text { linear dimension } \\
\text { and PCV } \\
\text { associated with } \\
\text { better visual } \\
\text { outcomes. }\end{array}$ \\
\hline $\begin{array}{l}\text { Khanani } \\
\text { et } a l^{28}\end{array}$ & $\begin{array}{l}\text { Retrospective } \\
\text { review }\end{array}$ & $\begin{array}{l}3 \text { loading doses } \\
\text { of aflibercept } \\
\text { followed by } \\
\text { bimonthly }\end{array}$ & 16 patients & $\begin{array}{l}\text { Approximately } \\
6 \text { months. }\end{array}$ & $\begin{array}{l}\text { Baseline } 62 \\
\text { EDTRS letters. } \\
\text { BCVA at month } \\
3 \text { was } 67 \text { EDTRS } \\
\text { letters. }\end{array}$ & $\begin{array}{l}\text { Baseline mean } \\
\text { of } 367 \text { microns. } \\
\text { At month } 3 \\
\text { decrease of } 76 \\
\text { microns. At visit } \\
5 \text { mild increase } \\
\text { of } 54.4 \text { microns } \\
\text { from month } 3 \\
\text { levels. }\end{array}$ & $\begin{array}{l}\text { Post 3rd } \\
\text { injection, } 44 \% \text { of } \\
\text { patients showed } \\
\text { a drop in VA ( } 7 \\
\text { patients) with } \\
\text { drop in VA at } \\
\text { visit } 4 \text { to } 63 \\
\text { EDTRS. }\end{array}$ \\
\hline $\begin{array}{l}\text { Matsumoto } \\
\text { et } a l^{32}\end{array}$ & $\begin{array}{l}\text { Retrospective } \\
\text { review }\end{array}$ & Treat and extend & $\begin{array}{l}17 \text { eyes with } \\
\text { RAP }\end{array}$ & 12 months & $\begin{array}{l}\text { Improvement } \\
\text { from } 0.57 \\
\text { logMAR to } 0.32\end{array}$ & $\begin{array}{l}\text { Decrease from } \\
340 \text { microns to } \\
133 \text { microns at } 1 \\
\text { year }(P<0.001)\end{array}$ & $\begin{array}{l}\text { Average } \\
\text { injections } 7.2 ; \\
\text { area of atrophy } \\
\text { increased by }\end{array}$ \\
\hline
\end{tabular}


Table 2. (Continued)

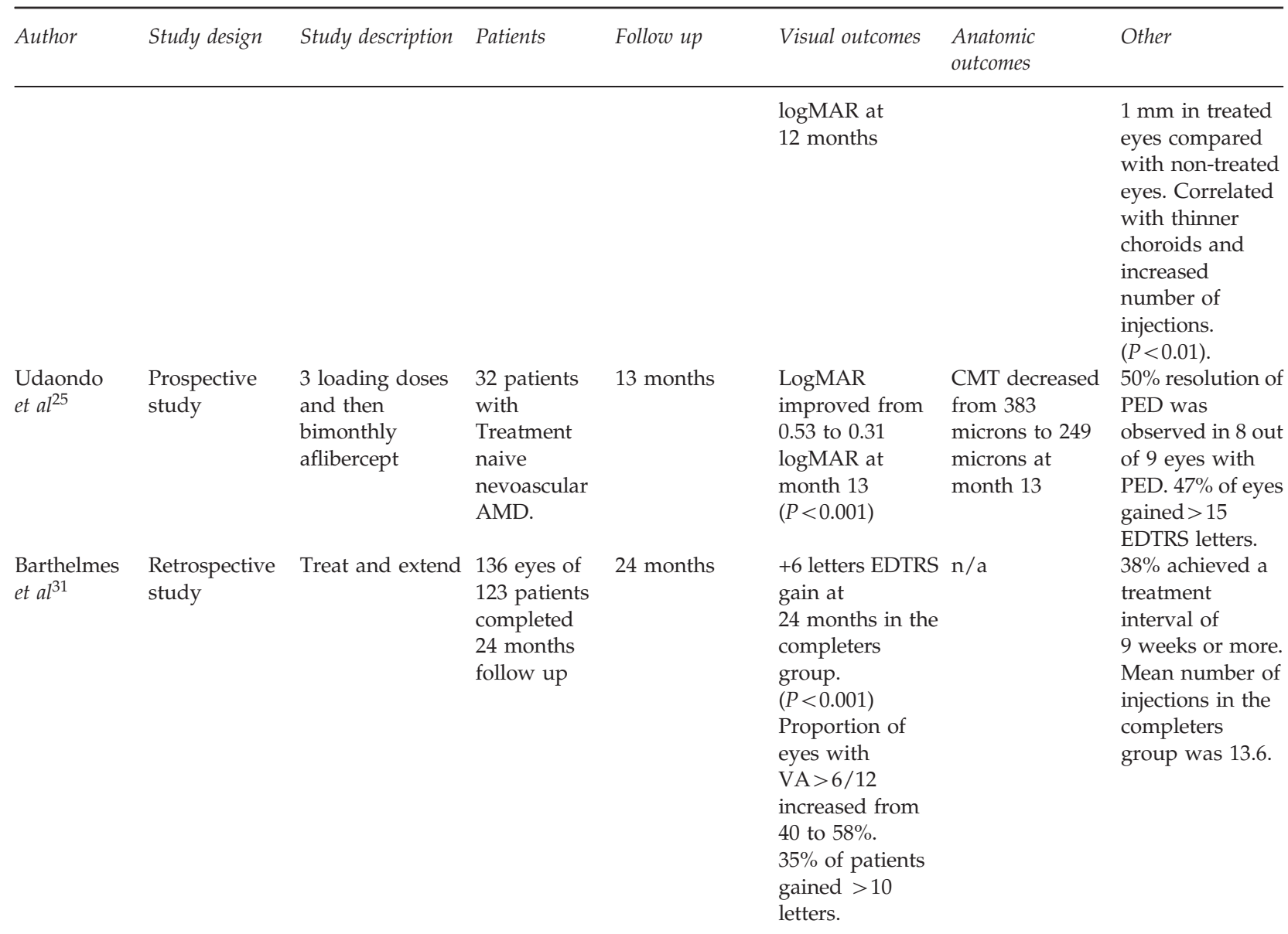

Abbreviations: AMD, age related macular degeneration; BCVA, best corrected visual acuity; CMT, central macular thickness; CNV, choroidal neovascularization; PCV, polypoidal choroidal vasculopathy; PED, pigment epithelial detachment; PRN, pro-re nata; RAP, retinal angiomatous proliferation.

treated with aflibercept for a duration of 1 year and showed that there was a mean improvement of BCVA from $0.73 \log$ MAR to $0.41 \log$ MAR with a mean of 4.3 injections. ${ }^{29}$ Similarly Inoue et al, looked at a cohort of 101 patients and demonstrated an improvement in BCVA from $0.37 \log$ MAR to $0.25 \log$ MAR. The study also showed that $63.5 \%$ of patients needed re-treatment and $36.5 \%$ of patients did not need further treatment. ${ }^{30}$

\section{TAE regimens with aflibercept}

The largest study looking at real world data for treat and extend regimens in treatment naive patients using aflibercept was a recent study by Barthelmes et al. ${ }^{31}$ The study was a retrospective study that included 136 eyes of 123 patients who completed 24 months of follow up (completers). At the end of follow up completers gained a mean of +6 EDTRS letters $(P<0.001)$. Approximately $98 \%$ of eyes starting with a visual acuity of $>70$ letters $(6 / 12)$ maintained it 24 months after treatment was started. The median time to $\mathrm{CNV}$ inactivity was 71 days with a median of three injections of aflibercept. The mean number of injections was 7.8 in the first year and 5.7 in the second year. During the second year of follow up, 38\% of patients achieved a treatment interval of 9 weeks or more.

A single study looked at the efficacy of aflibercept in a treat and extend dosing regimen (TAE) in patients with retinal angiomatous proliferation (RAP). ${ }^{32}$ The study looked at 17 eyes with RAP and found that after 12 months of follow up there was an improvement in VA from $0.57 \log$ MAR to $0.32 \log$ MAR. Also, the retinal thickness decreased from 340 microns before treatment and decreased to 233 months at the end of follow up $(P<0.001)$. It was also noted that the area of RPE atrophy significantly increased by the end of the study and correlated with increased number of injections ( $\mathrm{rs}=0.58$, $P=0.01)$. 
With regards to polypoidal choroidal vasculopathy, a single study looked at the at the efficacy of aflibercept in treatment naive patients with polypoidal choroidal vasculopathy (PCV). ${ }^{33}$ The study included 37 eyes and at one year the mean visual acuity improved form a baseline of $0.37 \log$ MAR to $0.21 \log$ MAR $(P<0.001)$. The mean treatment interval was 9.7 weeks with $60 \%$ of patients reaching extensions of 12 weeks or more.

\section{Aflibercept $v$ s ranibizumab}

The VIEW1/VIEW2 study demonstrated that monthly and bimonthly $2.0 \mathrm{mg}$ aflibercept achieved similar visual gains as monthly 0.5 ranibizumab (Table 3 ). In a prespecified integrated analysis, aflibercept was within 0.5 letters of the reference for mean change in BCVA. However, there were differences with regards to anatomy. The results of VIEW1/VIEW2 post hoc analysis demonstrated that both the $2 \mathrm{q} 4$ and the $2 \mathrm{q} 8$ groups had a significantly higher percentage of eyes with no fluid on OCT $(72.4 \%$ and $67.7 \%$, respectively) compared with the ranibizumab group $(62 \%)$ at week 52 . At week 52, IRC resolved in $57 \%, 50 \%$, and $52 \%$ of patients being treated with monthly aflibercept, bimonthly aflibercept and monthly ranibizumab, respectively. ${ }^{34}$ Subretinal fluid resolved in $75 \%$ of eyes treated with aflibercept compared with $66 \%$ of eyes treated with ranibizumab. Also PED resolved in $40 \%$ of eyes treated with monthly aflibercept, $34 \%$ of eyes treated bimonthly and $28 \%$ in eyes treated with ranibizumab. The post hoc analysis concluded that monthly aflibercept has a significantly stronger effect on fluid resolution in subretinal compartments such as subretinal fluid or PED. Bimonthly aflibercept seemed equivalent to monthly ranibizumab. As previously discussed, eyes with early persistent fluid achieve higher visual gains as well as anatomic dryness more frequently with monthly aflibercept compared with monthly ranibizumab or bimonthly aflibercept. ${ }^{19}$ In addition, these same eyes lose less vision when treated with monthly aflibercept indicating its added efficacy especially in eyes that fail to achieve dryness as 12 weeks.

There have been several studies that have compared between aflibercept and ranibizumab PRN dosing regimens, as illustrated in Table 2. However, none of these studies found a difference between both drugs with regards to visual outcomes. A study by Dirani et al looked exclusively at a cohort of patients with PED and after 3 loading doses of ranibizumab or aflibercept, the height of the PED decreased by 120 microns in both groups combined. ${ }^{35}$ In the multivariate analysis it was found that the use of aflibercept was associated with significantly more reduction in PED height $(P=0.022)$. A comparative study by Inoue et al, compared between PRN ranibizumab and aflibercept and found that although both groups showed a significant improvement from baseline, there was no difference between the visual improvements between both drugs. ${ }^{30}$ In addition, the mean time to retreatment was 5 months in both groups. Similar number of patients required retreatment in both groups (67.7 in the ranibizumab group vs $63.4 \%$ in the aflibercept group). In a Bayesian network meta-analysis, Szabo et al looked at five trials and found that over 12 months the approved posologies of aflibercept and ranibizumab resulted in similar changes in visual acuity from baseline. ${ }^{36}$ Finally, a study by Yun et al found that although visual outcomes were similar between aflibercept and ranibizumab, aflibercept was associated with a significantly greater reduction in subfoveal choroidal thickness. ${ }^{37}$ It is still unclear how the effect on choroidal thickness affects long term outcomes but at least with regards to recurrences it would seem that both drugs are similar. ${ }^{30}$

\section{Prognostic indicators of using aflibercept}

A post hoc analysis was conducted on 1815 patients enrolled in VIEW1/VIEW2 to look at morphological features that were associated with good visual outcomes. ${ }^{34}$ The analysis included the ranibizumab Q4 group as well as the $2 \mathrm{q} 4$ and $2 \mathrm{q} 8$ aflibercept group whilst excluding the $0.5 \mathrm{mg}$ group. The study looked at IRC, SRF as well as PED that was judged as present if it measured more than 400 microns in width and 75 microns in height or if the PED was only more than 200 microns in height.

With regards to prognostic indicators the multivariate model revealed that the presence of IRC and PED at baseline was associated with a 2.77 and 1.88 letters less BCVA change from baseline at week 52 . However, the presence of SRF was associated with 2.11 letters more BCVA change from baseline at week 52. In addition, higher baseline VA was associated with less visual gain regardless of the fluid morphology. IRC at baseline that had resolved at 3 months rarely recurred during the 1st year of treatment. ${ }^{22}$ However those with residual fluid at 12 weeks had more recurrences with at least $50 \%$ of patients demonstrating 5 or more recurrences indicating a more aggressive disease course. The study also demonstrated that visual losses in patients who were switched from fixed dosing regimens to PRN was mainly driven by eyes with primary PED. The switched to PRN group was associated with reactivation of the PED and development of secondary IRC with subsequent drop in visual acuity. The authors attributed the poor results of PRN dosing compared with monthly was mainly attributed to this subgroup.

Another study by Oishi et al, conducted on 98 patients showed that the presence of ELM and the presence of polypoidal lesions were associated with better visual 
Table 3 Summary of the studies comparing between aflibercept and ranibizumab as a primary treatment for wet AMD

\begin{tabular}{|c|c|c|c|c|c|c|c|}
\hline Author & Study design & Study description & Patients & Follow up & Visual outcomes & Anatomic outcomes & Other \\
\hline $\begin{array}{l}\text { VIEW1/ } \\
\text { VIEW2 }^{7}\end{array}$ & $\begin{array}{l}\text { Prospective, } \\
\text { double } \\
\text { masked, } \\
\text { randomized } \\
\text { trial }\end{array}$ & $\begin{array}{l}4 \text { groups; } 0.5 \mathrm{mg} \\
\text { ranibizumab } \\
\text { monthly(Rq4), } \\
2 \text { mg aflibercept } \\
\text { monthly (2q4), } \\
2 \text { mg aflibercept } \\
\text { bimonthly (2q8) } \\
\text { and } 0.5 \mathrm{mg} \\
\text { aflibercept monthly } \\
(0.5 \mathrm{q} 4)\end{array}$ & $\begin{array}{l}2419 \text { patients } \\
\text { randomized in } \\
\text { a 1:1:1:1 ratio }\end{array}$ & $\begin{array}{l}\text { Primary } \\
\text { end point } \\
\text { at } \\
12 \text { months. } \\
\text { Extension } \\
\text { period to } \\
96 \text { weeks; } \\
\text { PRN for all } \\
\text { groups. }\end{array}$ & $\begin{array}{l}+9.3 \text { letters gain } \\
2 \mathrm{q} 4,+8.7 \text { letter } \\
\text { Rq4,+8.4 letters } \\
2 \mathrm{q} 8,+8.3 \text { letters } \\
0.5 \mathrm{q} 4\end{array}$ & $\begin{array}{l}\text { Decrease in CMT } \\
\text { (VIEW1/VIEW2): } \\
-116 /-130 \text { microns } \\
\text { In } 0.5 q 4,-117 /-139 \\
\text { microns Rq4, }-117 /- \\
149 \text { microns } 2 \mathrm{q} 8 \\
\text { and }-129 /-157 \\
\text { microns in } 2 \mathrm{q} 4 \text {. }\end{array}$ & $\begin{array}{l}\text { All groups of } \\
\text { aflibercept were } \\
\text { non inferior to the } \\
\text { ranibizumab } \\
\text { group. }\end{array}$ \\
\hline $\begin{array}{l}\text { Dirani } \\
\text { et } a l^{35}\end{array}$ & $\begin{array}{l}\text { Retrospective } \\
\text { case series }\end{array}$ & $\begin{array}{l}\text { Patients were } \\
\text { treated with } 3 \\
\text { loading doses of } \\
\text { either ranibizumab } \\
(n=68) \text { or } \\
\text { aflibercept }(n=47)\end{array}$ & $\begin{array}{l}115 \text { eyes of } 102 \\
\text { patients with } \\
\text { treatment } \\
\text { naive AMD } \\
\text { and PED > } 150 \\
\text { microns }\end{array}$ & 3 months & $\begin{array}{l}\text { Overall } \\
\text { increase in } \\
\text { BCVA by }+7 \\
\text { EDTRS letters. } \\
\text { Drug type did } \\
\text { not affect visual } \\
\text { outcomes. }\end{array}$ & $\begin{array}{l}\text { Decrease in PED } \\
\text { height ( } 368 \text { microns } \\
\text { to } 248 \text { microns) and } \\
\text { central retinal } \\
\text { thickness ( } 328 \\
\text { microns to } 198 \\
\text { microns) }\end{array}$ & $\begin{array}{l}\text { Better visual } \\
\text { outcomes was } \\
\text { associated with } \\
\text { lower baseline } \\
\text { BCVA ( } P=0.001) \text {, } \\
\text { presence of SRF } \\
(P=0.001) \text { and } \\
\text { RAP }(P=0.001) \text {. } \\
\text { Reduction in PED } \\
\text { height was } \\
\text { associated with } \\
\text { higher PED at } \\
\text { baseline }(P=0.001) \text {, } \\
\text { Serous PED } \\
(P=0.003) \text { and } \\
\text { Aflibercept use } \\
(P=0.022) .\end{array}$ \\
\hline $\begin{array}{l}\text { Kim } \\
\text { et } a l^{29}\end{array}$ & $\begin{array}{l}\text { Retrospective } \\
\text { study }\end{array}$ & $\begin{array}{l}\text { Patients with } \\
\text { treatment naive } \\
\text { wet AMD were } \\
\text { treated with } 3 \\
\text { loading doses of } \\
\text { ranibizumab or } \\
\text { aflibercept and then } \\
\text { treated PRN }\end{array}$ & $\begin{array}{l}30 \text { eyes were } \\
\text { treated with } \\
\text { ranibizumab } \\
21 \text { eyes were } \\
\text { treated with } \\
\text { aflibercept }\end{array}$ & 12 months & $\begin{array}{l}\text { BCVA } \\
\text { improved from } \\
0.86 \pm 0.45 \\
\text { logMAR to } \\
0.72 \pm 0.56 \\
\text { logMAR in } \\
\text { ranibizumab } \\
\text { group } \\
\text { Mean BCVA } \\
\text { improved form } \\
0.73 \pm 0.37 \\
\text { logMAR to } \\
0.58 \pm 0.41 \\
\text { logMAR in the } \\
\text { aflibercept } \\
\text { group } \\
\text { No significant } \\
\text { difference with } \\
\text { regards to } \\
\text { visual } \\
\text { improvement } \\
\text { (P=0.560) }\end{array}$ & NS & $\begin{array}{l}\text { Mean number of } \\
\text { injections was } \\
4.5 \pm 1.3 \text { in the } \\
\text { ranibizumab group } \\
\text { and } 4.3 \pm 0.9 \text { in the } \\
\text { aflibercept group } \\
\text { No significant } \\
\text { difference between } \\
\text { them in number of } \\
\text { injections. }\end{array}$ \\
\hline $\begin{array}{l}\text { Inoue } \\
\text { et } a l^{30}\end{array}$ & $\begin{array}{l}\text { Retrospective } \\
\text { interventional } \\
\text { comparative } \\
\text { study }\end{array}$ & $\begin{array}{l}3 \text { loading doses of } \\
\text { the drug followed } \\
\text { by PRN therapy. }\end{array}$ & $\begin{array}{l}200 \text { eyes of } 197 \\
\text { patients; } 99 \\
\text { patients in the } \\
\text { ranibizumab } \\
\text { group and } 101 \\
\text { patients in the } \\
\text { aflibercept } \\
\text { group }\end{array}$ & 12 months & $\begin{array}{l}\text { The mean } \\
\text { logMAR visual } \\
\text { acuity at } \\
\text { the baseline } \\
\text { was } 0.44 \pm 0.33 \\
\text { in the IVR } \\
\text { group and } \\
0.37 \pm 0.37 \text { in } \\
\text { the IVA group. } \\
\text { The mean } \\
\text { logMAR BCVA } \\
\text { at } 12 \text { months }\end{array}$ & $\begin{array}{l}\text { Mean changes in } \\
\text { CFT at } 12 \text { months } \\
\text { was } 103 \pm \\
130 \mu \mathrm{m} \text { in the IVR } \\
\text { group and } \\
95 \pm 113 \mu \mathrm{m} \text { in the } \\
\text { IVA group, } \\
\text { respectively. } \\
\text { No significant } \\
\text { differences between } \\
\text { the two drugs. }\end{array}$ & $\begin{array}{l}\text { Median time to } \\
\text { retreatment after } \\
\text { loading doses was } \\
5 \text { months in both } \\
\text { groups. } \\
67.7 \% \text { of patients in } \\
\text { the ranibizumab } \\
\text { group and } 63.4 \% \text { in } \\
\text { the aflibercept } \\
\text { group required } \\
\text { retreatment } \\
(P=0.554) .\end{array}$ \\
\hline
\end{tabular}


Table 3. (Continued)

\begin{tabular}{|c|c|c|c|c|c|c|c|}
\hline Author & Study design & Study description & Patients & Follow up & Visual outcomes & Anatomic outcomes & Other \\
\hline $\begin{array}{l}\text { Yun } \\
\text { et } a l^{37}\end{array}$ & $\begin{array}{l}\text { Retrospective } \\
\text { study }\end{array}$ & $\begin{array}{l}3 \text { loading doses of } \\
\text { either ranibizumab } \\
\text { or aflibercept }\end{array}$ & $\begin{array}{l}54 \text { treatment } \\
\text { naive, } \\
\text { consecutive } \\
\text { eyes. } \\
21 \text { eyes treated } \\
\text { with } \\
\text { aflibercept and } \\
33 \text { eyes treated } \\
\text { with } \\
\text { ranibizumab }\end{array}$ & 3 months & $\begin{array}{l}\text { was } \\
0.37 \pm 0.41 \text { in } \\
\text { the IVR group } \\
\text { and } \\
0.25 \pm 0.40 \text { in } \\
\text { the IVA group, } \\
\text { respectively, } \\
\text { a significant } \\
\text { improvement } \\
\text { from baseline } \\
P<0.05 \text {. No } \\
\text { significant } \\
\text { difference } \\
\text { between both } \\
\text { treatment } \\
\text { groups. } \\
\text { BCVA } \\
\text { improved in } \\
\text { the aflibercept } \\
\text { group from } \\
0.41 \text { logMAR to } \\
0.23 \text { loMAR. } \\
(P=0.001) \\
\text { In the } \\
\text { ranibizumab } \\
\text { group BCVA } \\
\text { improved from } \\
0.66 \text { logMAR to } \\
0.49 \text { logMAR. } \\
\text { ( } P=0.004)\end{array}$ & NS & $\begin{array}{l}\text { Mean subfoveal } \\
\text { choroidal thickness } \\
(\mathrm{CT}) \text { were matched } \\
\text { at baseline. The } \\
\text { decrease in } \\
\text { subfoveal CT was } \\
\text { greater in the } \\
\text { aflibercept group } \\
\text { than in } \\
\text { ranibizumab } \\
(P=0.024) .\end{array}$ \\
\hline
\end{tabular}

outcomes. $\left(\mathrm{R}^{2}=0.53, P<0.0001\right) .{ }^{27}$ A study by Cho et al, looking at the response of patients with PED to anti-VEGF therapy found that patients with lower PED height, PCV $(P=0.15)$, RAP compared with typical AMD $(0.01)$, serous PED vs fibrovascular PED $(P=0.022)$ and aflibercept compared with ranibizumab $(P=0.039)$ had a higher possibility of PED resolution. ${ }^{38}$ Also, a study conducted on 47 eyes by Kikushima et al, showed that patients with thicker choroids $(P=0.004)$ and worse baseline visual acuity $(P=0.018)$ achieved more visual gains. ${ }^{39}$

\section{Ziv-Aflibercept (off-label aflibercept)}

An identical fusion protein to aflibercept is ziv-aflibercept (Zaltrap, Sanofi-Aventis US, LLC, Bridgewater, New Jersey, USA and Regeneron Pharmaceuticals, Inc, Tarrytown, New York, USA) that was approved by the FDA in August 2012 for the treatment of metastatic colorectal carcinoma. Both aflibercept and ziv-aflibercept are structurally identical however ziv-aflibercept has been formulated with buffers that result in a much higher osmolality. Recent case series have shown that zivaflibercept can be safely used as an intra-vitreal drug, complementing previous animal and in vitro studies. ${ }^{40-44}$ The higher cost of aflibercept means that many patients are unable to afford the more expensive drug and zivaflibercept may be a reasonable economic choice for patients as an alternative to bevacizumab. One of the main differences, between aflibercept and ziv-aflibercept is the difference in osmolarity with aflibercept being an iso-osmotic solution (300 mOsm $/ \mathrm{kg}$ ), whereas the buffers in ziv-aflibercept make it far more concentrated (1000 $\mathrm{mOsm} / \mathrm{kg}$ ).

Initial data from Marmor et al, ${ }^{45}$ showed that in rabbits and primates solutions less that 500 mOsm caused no retinal pigment epithelium damage whereas tonicitiy between 500 and 1000 mOsm produced partial damage and those above 2000 mOsm produced severe damage. This initially led to some reservations about using the more hypertonic concentration of ziv-aflibercept. Another cause for concern was a study by Malik et $a l^{43}$ that showed that at clinical doses ziv-aflibercept showed mild mitochondrial toxicity whereas ranibizumab and aflibercept did not. However, the study also showed that bevacizumab, a drug that is widely used intravitreally, showed similar mitochondrial toxicity bringing into 
question its in-vivo applicability. Furthermore a study looking into the injection of ziv-aflibercept in rabbit eyes has shown that it was equally as safe as aflibercept with no signs of anatomic toxicity after 7 days. In addition, there are no statistically significant differences between both drugs in recorded by ERG $24 \mathrm{~h}$ or one week after the procedure. Even more interesting, there were no statistical differences in aqueous $\mathrm{pH}$ and osmolality at baseline and in follow-up indicating that ziv-aflibercept had no major impact on eye osmolality. Mansour et al, ${ }_{1}^{44}$ proposed that this might be due to the diluting effect of injecting a $0.05 \mathrm{ml}$ dose into $4 \mathrm{ml}$ of vitreous.

The largest cohort of patients with AMD treated with ziv-aflibercept was by Mansour et al 30 eyes were treated and the 3 month evaluation showed an improvement of baseline VA from $1.08 \log$ MAR to $0.71 \log$ MAR $(P<0.001) .{ }^{46}$ In addition, central macular thickness decreased form 332.9 microns to 208.2 microns at 3 months. There were no signs of any intraocular inflammation or complications. Of note the dose used in the study was $0.05 \mathrm{ml}$ which contains approximately $1.25 \mathrm{mg}$ of the active molecule compared with the usual dose of $2.0 \mathrm{mg} / 0.05 \mathrm{ml}$. Therefore, it is still unclear if the efficacy of ziv-aflibercept is equivalent to aflibercept and if it can be effectively incorporated into dosing regimens such as bimonthly or TAE.

\section{Algorithm for fixed treatment regimen in aflibercept}

Patients should be treated with three loading doses of aflibercept and re-evaluated at 3 months. Patients with residual fluid at three months (regardless type of fluid) should be treated with monthly aflibercept until they achieve dryness. If at 12 months no dryness has been achieved, switching may be attempted, however there is insufficient data about switching from aflibercept to other anti-VEGF drugs. Patients with no fluid at 3 months could be treated bimonthly or using a treat and extend protocol. After 1 year, we recommend fixed bimonthly dosing for patients with active disease but stable visual acuity at the end of year 1 and TAE for eyes with inactive disease and stable visual acuity.

\section{Conclusion}

Aflibercept is an effective drug in the treatment of wet AMD. The efficacy of monthly and bimonthly dosing regimens of aflibercept are comparable to monthly ranibizumab. There is data preliminary showing that PRN dosing of both aflibercept and ranibizumab yields similar results. There is insufficient data about aflibercept in a treat and extend regimen. Monthly aflibercept appears to be anatomically superior to ranibizumab especially in patients with residual fluid at 12 weeks and particularly those with residual subretinal fluid. PRN dosing results in a drop in visual acuity after the first year of fixed dosing so it is recommended that either patients be maintained on fixed dosing or a treat and extend regimen. Ziv-aflibercept appears to be new option in the treatment of wet AMD, however more data are needed with regards to long term safety and efficacy.

\section{Conflict of interest}

The authors declare no conflict of interest.

\section{References}

1 Smith W, Assink J, Klein R, Mitchell P, Klaver CC, Klein BE et al. Risk factors for age-related macular degeneration: Pooled findings from three continents. Ophthalmology 2001; 108(4): 697-704.

2 Ferris FL 3rd, Fine SL, Hyman L. Age-related macular degeneration and blindness due to neovascular maculopathy. Arch Ophthalmol 1984; 102(11): 1640-1642.

3 Yancopoulos GD. Clinical application of therapies targeting VEGF. Cell 2010; 143(1): 13-16.

4 Ferrara N. VEGF-A: a critical regulator of blood vessel growth. Eur Cytokine Netw 2009; 20(4): 158-163.

5 Brown DM, Kaiser PK, Michels M, Soubrane G, Heier JS, Kim RY et al. Ranibizumab versus Verteporfin for Neovascular Age-Related Macular Degeneration. N Engl J Med 2006; 355(14): 1432-1444.

6 Rosenfeld PJ, Brown DM, Heier JS, Boyer DS, Kaiser PK, Chung CY et al. Ranibizumab for neovascular age-related macular degeneration. N Engl J Med 2006; 355(14): 1419-1431.

7 Heier JS, Brown DM, Chong V, Korobelnik JF, Kaiser PK, Nguyen QD et al. Intravitreal aflibercept (VEGF trap-eye) in wet age-related macular degeneration. Ophthalmology 2012; 119(12): 2537-2548.

8 Rakic JM, Lambert V, Devy L, Luttun A, Carmeliet P, Claes $C$ et al. Placental growth factor, a member of the VEGF family, contributes to the development of choroidal neovascularization. Invest Ophthalmol Vis Sci 2003; 44(7): 3186-3193.

9 Huo X, Li Y, Jiang Y, Sun X, Gu L, Guo W et al. Inhibition of ocular neovascularization by co-inhibition of VEGF-A and PLGF. Cell Physiol Biochem 2015; 35(5): 1787-1796.

10 Papadopoulos N, Martin J, Ruan Q, Rafique A, Rosconi MP, Shi E et al. Binding and neutralization of vascular endothelial growth factor (VEGF) and related ligands by VEGF Trap, ranibizumab and bevacizumab. Angiogenesis 2012; 15(2): 171-185.

11 Stewart MW. Pharmacokinetics, pharmacodynamics and pre-clinical characteristics of ophthalmic drugs that bind VEGF. Expert Rev Clin Pharmacol 2014; 7(2): 167-180.

12 Christoforidis JB, Carlton MM, Knopp MV, Hinkle GH. PET/CT imaging of I-124-radiolabeled bevacizumab and ranibizumab after intravitreal injection in a rabbit model. Invest Ophthalmol Vis Sci 2011; 52(8): 5899-5903.

13 Korobelnik JF, Do DV, Schmidt-Erfurth U, Boyer DS, Holz FG, Heier JS et al. Intravitreal aflibercept for diabetic macular edema. Ophthalmology 2014; 121(11): 2247-2254.

14 Lalwani GA, Rosenfeld PJ, Fung AE, Dubovy SR, Michels S, Feuer $\mathrm{W}$ et al. A variable-dosing regimen with intravitreal 
ranibizumab for neovascular age-related macular degeneration: year 2 of the PrONTO Study. Am J Ophthalmol 2009; 148(1): 43-58 e41.

15 Wykoff CC, Croft DE, Brown DM, Wang R, Payne JF, Clark L et al. Prospective Trial of Treat-and-Extend versus Monthly Dosing for Neovascular Age-Related Macular Degeneration: TREX-AMD 1-Year Results. Ophthalmology 2015; 122(12): 2514-2522.

16 Kaiser PK, Brown DM, Zhang K, Hudson HL, Holz FG, Shapiro $\mathrm{H}$ et al. Ranibizumab for predominantly classic neovascular age-related macular degeneration: subgroup analysis of first-year ANCHOR results. Am J Ophthalmol 2007; 144(6): 850-857.

17 Boyer DS, Antoszyk AN, Awh CC, Bhisitkul RB, Shapiro H, Acharya NR et al. Subgroup analysis of the MARINA study of ranibizumab in neovascular age-related macular degeneration. Ophthalmology 2007; 114(2): 246-252.

18 Moshfeghi DM, Hariprasad SM, Marx JL, Thompson D, Soo Y, Gibson A et al. Effect of Fluid Status at Week 12 on Visual and Anatomic Outcomes at Week 52 in the VIEW 1 and 2 Trials. Ophthal Surg Lasers Imag Retina 2016; 47(3): 238-244.

19 Jaffe GJ, Kaiser PK, Thompson D, Gibson A, Saroj N, Vitti R et al. Visual acuity of eyes with early persistent retinal fluid from neovascular age-related macular degeneration in the VIEW studies. Ophthalmology 2016; 123(9): 1856-1864.

20 Schmidt-Erfurth U, Kaiser PK, Korobelnik JF, Brown DM, Chong V, Nguyen QD et al. Intravitreal aflibercept injection for neovascular age-related macular degeneration: ninetysix-week results of the VIEW studies. Ophthalmology 2014; 121(1): 193-201.

21 Richard G, Mones J, Wolf S, Korobelnik JF, Guymer R, Goldstein $\mathrm{M}$ et al. Scheduled versus Pro Re Nata Dosing in the VIEW trials. Ophthalmology 2015; 122(12): 2497-2503.

22 Schmidt-Erfurth U, Waldstein SM, Deak GG, Kundi M, Simader C. Pigment epithelial detachment followed by retinal cystoid degeneration leads to vision loss in treatment of neovascular age-related macular degeneration. Ophthalmology 2015; 122(4): 822-832.

23 McKibbin M, Devonport H, Gale R, Gavin M, Lotery A, Mahmood S et al. Aflibercept in wet AMD beyond the first year of treatment: recommendations by an expert roundtable panel. Eye (Lond) 2015; 29 Suppl 1: S1-S11.

24 Talks JS, Lotery AJ, Ghanchi F, Sivaprasad S, Johnston RL, Patel $\mathrm{N}$ et al. First-year visual acuity outcomes of providing aflibercept according to the VIEW study protocol for agerelated macular degeneration. Ophthalmology 2016; 123(2): 337-343.

25 Udaondo P, Salom D, Garcia-Delpech S, Cisneros-Lanuza A Aflibercept as first-line therapy in patients with treatmentnaive neovascular age-related macular degeneration: prospective case series analysis in real-life clinical practice. Ophthalmologica 2016; 236(1): 29-35.

26 Zinkernagel MS, Wolf S, Ebneter A. Fluctuations in pigment epithelial detachment and retinal fluid using a bimonthly treatment regimen with aflibercept for neovascular age-related macular degeneration. Ophthalmologica 2016; 235(1): 42-48.

27 Oishi A, Tsujikawa A, Yamashiro K, Ooto S, Tamura H, Nakanishi $\mathrm{H}$ et al. One-year result of aflibercept treatment on age-related macular degeneration and predictive factors for visual outcome. Am J Ophthalmol 2015; 159(5): 853-860. e1.

28 Khanani AM. Clinical experience with fixed bimonthly aflibercept dosing in treatment-experienced patients with neovascular age-related macular degeneration. Clin Ophthalmol 2015; 9: 1315-1320.
29 Kim JH, Lee DW, Chang YS, Kim JW, Kim CG Twelve-month outcomes of treatment using ranibizumab or aflibercept for neovascular age-related macular degeneration: a comparative study. Graefes Arch Clin Exp Ophthalmol 2016; 254(11): 2101-2109.

30 Inoue M, Yamane S, Sato S, Sakamaki K, Arakawa A, Kadonosono K. Comparison of time to retreatment and visual function between ranibizumab and aflibercept in age-related macular degeneration. Am J Ophthalmol 2016; 169: 95-103.

31 Barthelmes D, Nguyen V, Daien V, Campain A, Walton R, Guymer R et al. Two year outcomes of 'treat and extend' intravitreal therapy using aflibercept preferentially for neovascular age-related macular degeneration. Retina 2017; e-pub ahead of print 31 January 2017; doi:10.1097/IAE.0000000000001496.

32 Matsumoto H, Sato T, Morimoto M, Mukai R, Takahashi M, Hiroe $\mathrm{T}$ et al. Treat-and-extend regimen with aflibercept for retinal angiomatous proliferation. Retina 2016; 36(12): 2282-2289.

33 Hosokawa M, Morizane Y, Hirano M, Kimura S, Kumase F, Shiode $\mathrm{Y}$ et al. One-year outcomes of a treat-and-extend regimen of intravitreal aflibercept for polypoidal choroidal vasculopathy. Jpn J Ophthalmol 2016; 61(2): 150-158.

34 Waldstein SM, Simader C, Staurenghi G, Chong NV, Mitchell P, Jaffe GJ et al. Morphology and visual acuity in aflibercept and ranibizumab therapy for neovascular agerelated macular degeneration in the VIEW Trials. Ophthalmology 2016; 123(7): 1521-1529.

35 Dirani A, Ambresin A, Marchionno L, Decugis D, Mantel I. Factors influencing the treatment response of pigment epithelium detachment in age-related macular degeneration. Am J Ophthalmol 2015; 160(4): 732-738. e732.

36 Szabo SM, Hedegaard M, Chan K, Thorlund K, Christensen R, Vorum $\mathrm{H}$ et al. Ranibizumab vs. aflibercept for wet agerelated macular degeneration: network meta-analysis to understand the value of reduced frequency dosing. Curr Med Res Opin 2015; 31(11): 2031-2042.

37 Yun C, Oh J, Ahn J, Hwang SY, Lee B, Kim SW et al. Comparison of intravitreal aflibercept and ranibizumab injections on subfoveal and peripapillary choroidal thickness in eyes with neovascular age-related macular degeneration. Graefes Arch Clin Exp Ophthalmol 2016; 254(10): 1693-1702.

38 Cho HJ, Kim KM, Kim HS, Lee DW, Kim CG, Kim JW. Response of Pigment Epithelial Detachment to Anti-Vascular Endothelial Growth Factor Treatment in Age-Related Macular Degeneration. Am J Ophthalmol 2016; 166: 112-119.

39 Kikushima W, Sakurada Y, Sugiyama A, Tanabe N, Kume A, Iijima H. Factors Predictive of Visual Outcome 1 Year After Intravitreal Aflibercept Injection for Typical Neovascular Age-Related Macular Degeneration. J Ocul Pharmacol Ther 2016; 32(6): 376-382.

40 Chhablani J. Intravitreal ziv-aflibercept for recurrent macular edema secondary to central retinal venous occlusion. Indian J Ophthalmol 2015; 63(5): 469-470.

41 Chhablani J, Narayanan R, Mathai A, Yogi R, Stewart M. Short-term safety profile of intravitreal ziv-aflibercept. Retina 2016; 36(6): 1126-1131.

42 Dias JRdO, Badaró E, Novais E, Colicchio D, Matioli M, Hirai FE et al. Pre-clinical safety of intravitreal zivaflibercept. Investig Ophthalmol Vis Sci 2014; 55(13): 1948-1948.

43 Malik D, Tarek M, Caceres del Carpio J, Ramirez C, Boyer D, Kenney MC et al. Safety profiles of anti-VEGF drugs: bevacizumab, ranibizumab, aflibercept and ziv-aflibercept 
on human retinal pigment epithelium cells in culture. $\mathrm{Br}$ Ophthalmol 2014; 98(Suppl 1): i11-i16.

44 Mansour AM, Al-Ghadban SI, Yunis MH, El-Sabban ME. Ziv-aflibercept in macular disease. Br J Ophthalmol 2015; 99(8): 1055-1059.

45 Marmor MF, Martin LJ, Tharpe S. Osmotically induced retinal detachment in the rabbit and primate. Electron miscoscopy of the pigment epithelium. Invest Ophthalmol Vis Sci 1980; 19(9): 1016-1029.

46 Mansour AM, Chhablani J, Antonios RS,

Yogi R, Younis MH, Dakroub R et al. Three-month outcome of ziv-aflibercept for exudative age-related macular degeneration. Br J Ophthalmol 2016; 100(12): 1629-1633. 